\title{
The challenges of the medical doctors working in the intensive care unit during COVID-19 pandemic
}

\section{COVID-19 salgını sırasında yoğun bakım ünitesinde çalışan doktorların yaşadığı zorluklar}

\author{
Helin SAHINTURK* $\square$, Irem Ulutas ORDU⿴囗十, Aykan GULLEROGLU⿴囗十, Fatma Irem YESILER Q, \\ Manat AITHAKANOVA $\square$, Ender GEDIK $\square$, Pinar ZEYNELOGLU $\square$
}

Baskent University Faculty of Medicine, Department of Anesthesiology and ICM, Ankara/TURKEY

\begin{abstract}
Aim: Healthcare professionals working in intensive care unit (ICU) have been in the frontline from the beginning of COVID-19 pandemic. We aimed to evaluate the technical and psychological difficulties encountered by medical doctors working in the ICU of the hospitals within Başkent University Faculty of Medicine during this pandemic.

Material and Methods: A questionnaire consisting of 52 questions was applied to the medical doctors working in the ICUs of Başkent University affiliated centers.

Personal protective equipment (PPE) includes; surgical mask, N95: N95 mask, face shield, glove, overalls, overshoe, goggles, intubation cabin.

Results: Out of the 73 ICU physicians who were invited to participate, 62 (84.9\%) of them completed the survey. Out of $59.7 \%$ of the participants stated that they did not feel safe while caring for the patients. The most common reason for their insecurity was the fear of contamination (70.3\%). Out of 69.4\% ICU physicians stated that their anxiety level was moderate. It was observed that the anxiety level of ICU physicians decreased as the number of patients followed up increased ( $p=$ 0.025), the increase in the number of hospital beds was found to be significantly associated with increased anxiety level $(p=0.015)$. It was found that the presence of anxiety complaint increased the state of having high anxiety related to COVID-19 disease 28.3 times $(p=0.001)$.

Conclusion: We found that more than half of the physicians participating in our study didn't have any problem of protective personal equipment (PPE) deficiency, which is one of the most important technical difficulties. Regarding psychological difficulties, we found that doctors who had anxiety complaints before had much more difficulties in managing the pandemic process than others.
\end{abstract}

Keywords: Covid-19 pandemic; intensive care unit (ICU); anxiety

Corresponding Author*: Helin Sahinturk, Baskent University Faculty of Medicine, Department of Anesthesiology and ICM, Ankara/TURKEY 


\section{Öz}

Amaç: Yoğun bakım ünitesinde (YBÜ) çalışan sağlık çalışanları, COVID-19 salgınının başlangııından itibaren ön saflarda yer aldı. Başkent Üniversitesi Tıp Fakültesi bünyesindeki hastanelerin yoğun bakım ünitelerinde görev yapan doktorların, bu pandemi sürecinde karşılaştıkları teknik ve psikolojik zorlukları değerlendirmeyi amaçladık.

Gereç ve Yöntemler: Başkent Üniversitesine bağlı merkezlerin yoğun bakım ünitelerinde çalışan doktorlara 52 sorudan oluşan anket uygulanmıştır.

Bulgular: Çalışmaya davet edilen 73 yoğun bakım doktorundan 62'si $(\% 84,9)$ anketi tamamladı. Katılımcıların $\% 59,7$ 'si hastalara bakarken kendilerini güvende hissetmediklerini belirtmişlerdir. Güvensizliklerinin en yaygın nedeni kontaminasyon korkusuydu (\%70,3). YBÜ doktorlarının \%69,4'ü kaygı düzeylerinin orta düzeyde olduğunu belirtmiştir. Takip edilen hasta sayısı arttıkça YBÜ doktorlarının kaygı düzeyinin azaldığı $(p=0,025)$, hastane yatak sayısındaki artışın kaygı düzeyinin artmasıyla anlamlı olarak ilişkili olduğu $(p=0,015)$ görüldü. Öncesinde var olan anksiyete şikayetinin, COVID-19 hastalığına ilişkin anksiyeteyi 28,3 kat arttırdığı tespit edildi $(p=0,001)$.

Sonuç: Çalışmamıza katılan doktorların yarısından fazlasının en önemli teknik zorluklardan biri olan kişisel koruyucu ekipman (KKE) eksikliği sorununu yaşamadığını tespit ettik.

Psikolojik zorluklar söz konusu olduğunda, daha önce anksiyete şikayetleri olan doktorların pandemi sürecini yönetmede diğerlerine göre çok daha fazla zorluk yaşadıklarını gördük.

Anahtar kelimeler: Covid-19 pandemisi; yoğun bakım ünitesinde (YBÜ); anksiyete

\section{Introduction}

Coronavirus infection (COVID-19), which was declared as a pandemic by the World Health Organization on March 11, 2020, was first reported in Wuhan, China, on December 31, 2019.[1,2] The mortality of this infection, which progresses with high fever, shortness of breath, and bilateral pulmonary infiltrate, has been reported as 3.8\%.[1]

The novel human coronavirus disease, caused by a singlestranded, enveloped RNA virus, is transmitted via respiratory droplets and direct contact and keeps spreading worldwide. It is stated that contagiousness can start 1 to 2 days before the symptomatic period and continue until the fourteenth day after the symptoms occur.2 In case of severe pneumonia, respiratory failure, and /or deterioration in organ functions, mechanical ventilation and intensive care follow-up are essential..[2,3]

The pandemic list of the World Health Organization consists of a wide spectrum, starting with the plague infection in 1347, continuing with Cholera, Russian flu, Spanish flu, Asian flu, AIDS, and Influenza infections, and finally, Covid-19 infection. $[4,6]$ The novel pandemic highlights the intense stress effects on healthcare workers.[4,6] Healthcare professionals responsible for the treatment of suspected or confirmed cases are at risk in terms of increased transmission as well as mental health problems.[7] Our study aimed to evaluate the technical and psychological difficulties encountered by medical doctors working in the intensive care unit (ICU) of the hospitals within Başkent University Faculty of Medicine during this pandemic.

\section{Materials and methods}

Medical doctors working in the ICUs of Başkent Universityaffiliated centers in other cities (Ankara Hospital, Adana Hospital, İstanbul Hospital, İzmir Hospital, Konya Hospital, and Alanya Hospital) during the COVID-19 pandemic were included in this prospective study. This study was approved by the Başkent University Institutional Review Board (project no KA 20/217). The coordinator center of the study is Başkent University Ankara Hospital. This study was on a voluntary basis. A questionnaire consisting of 52 questions was applied to the medical doctors who accepted to participate in the study. The questionnaire is shared in Annex 1.

Personal protective equipment (PPE) includes; surgical mask, N95: N95 mask, face shield, glove, overalls, overshoe, goggles, intubation cabin.

The primary outcome of the study is to identify the technical and psychological difficulties faced by ICU physicians during the COVID-19 pandemic.

The secondary outcome of the study is identifying factors that affect the anxiety of doctors. 


\section{Statistical Analysis}

Data were summarized as mean \pm standard deviation and median (minimum-maximum) for continuous variables, frequencies (percentiles) for categorical variables. Student's t-test was used for independent group comparisons. Chisquare test was used for proportions, and its counterpart Fisher's Exact Test was used when the data were sparse. The association between anxiety focused on being high or medium-level was evaluated by multiple logistic regression analysis. Odds ratios and their confidence intervals were calculated. A "p" value of less than 0.05 was considered statistically significant, and SPSS 15.0 for Windows was used for all these statistical analyzes.

\section{Results}

Out of 73 ICU physicians who were invited to participate, 62 (84.9\%) of them working in the ICU completed the survey. The mean age was 39.6 \pm 9.1 (between 27-60 years old), and $69.4 \%$ of them were female $(n=43)$. The medical specialist (most of them anesthesiologist) group constituted the highest percentage (40.3\%) of the survey participants (Table-1).

\begin{tabular}{|c|c|c|}
\hline \multicolumn{3}{|c|}{ Table-1: Demographic Characteristics of Doctors } \\
\hline Variables & Mean \pm SD & Median (Min.-Max.) \\
\hline \multirow[t]{2}{*}{ Age (years) } & $39.6 \pm 9.1$ & $40.0(27-60)$ \\
\hline & Frequency (n) & Percent (\%) \\
\hline Female/Male & $43 / 19$ & $69.4 / 30.6$ \\
\hline \multicolumn{3}{|l|}{ Academic title } \\
\hline General practitioner & 5 & 8.1 \\
\hline Resident & 22 & 35.5 \\
\hline Medical Specialist & 25 & 40.3 \\
\hline Assistant professor & 3 & 4.8 \\
\hline Associate professor & 2 & 3.2 \\
\hline Professor & 5 & 8.1 \\
\hline
\end{tabular}

Out of $91.9 \%$, ICU physicians stated that they were working in mixed medical and surgical ICUs, and 95.2\% stated that they had mixed type rooms both isolation rooms and open wards. Sixty-one (98.4\%) participants stated that they created a different ICU for COVID-19 real time polymerase chain reactions (PCR) positive patients due to the Covid-19 pandemic. Fifty-two (83.9\%) participants had negative pressure isolation rooms.

According to the survey results, 39 (62.9\%) of the participants reported having sufficient medical doctors in the ICU, while 27 (43.5\%) of the participants reported having sufficient nurses.
While the mean working duration of doctors was 11.2 \pm 5.5 (6-30 hours) hours per shift, the same time was $10.7 \pm 1.9$ (6-12 hours) for nurses. The maximum shift duration among doctors was 24 hours (45.2\%), it was less than 24 hours among nurses (91.9\%) (Table-2). For doctors with a shift duration of more than 24 hours, the mean shift duration was $28.7 \pm 4.0$ hours (26-36 hours). The mean number of patients a doctor and a nurse has to care for in one shift was $11.4 \pm 6.7$ (4-36), $3.5 \pm 4.1$ (2-21), respectively. Eighty point six percent of the participants stated that $(n=50)$ there was a specialist doctor in the ICU for 24 hours and their specialty was reported as anesthesiology by 26 participants (41.9\%). The specialty distributions of non-anesthesiologist ICU doctors were internal diseases $(n=3)$, infectious diseases $(n=2)$, general surgery and cardiology $(n=1)$ (Table-3).

\begin{tabular}{|c|c|c|}
\hline & Frequency (n) & Percent (\%) \\
\hline \multicolumn{3}{|c|}{ Duration of a shift for doctors } \\
\hline$<24$ hours & 19 & 30.6 \\
\hline 24 hours & 28 & 45.2 \\
\hline$>24$ hours & 15 & 24.2 \\
\hline \multicolumn{3}{|c|}{ Duration of a shift for nurses } \\
\hline$<24$ hours & 57 & 91.9 \\
\hline 24 hours & 3 & 4.8 \\
\hline$>24$ hours & 2 & 3.2 \\
\hline
\end{tabular}

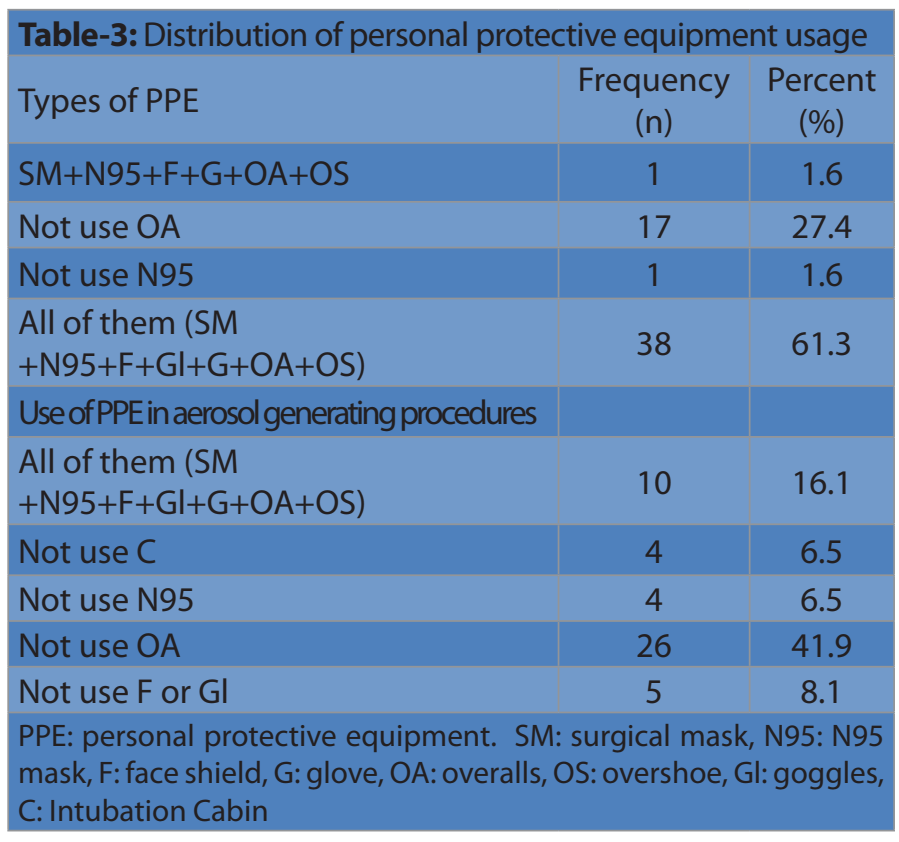

Sixty six point one percent of the participants $(n=41)$ stated that the same doctors worked at COVID-19 ICUs and non COVID-19 ICUs. Additionally, 85.2\% $(n=52)$ stated that nonICU teams were not included in the ICU working order. In the emergency department, it was found that all three branches, 
emergency service, infectious diseases and chest diseases physicians actively participated in the management of COVID-19 patients ( $n=34$ / 55.7\%).

The admissions of the patients to the ICU were done by $30.6 \%$ of the ICU doctors and the others by the relevant branch doctors. In $85.5 \%$ ( $n=53$ ) of the centers, patients were followed up as closed format intensive care units. It was found that $41.9 \%$ ( $n=$ 26) of the patients who were primarily hospitalized by intensive care physicians had a problem with their transfer to the ward after recovery. It was stated that $25.8 \%(n=16)$ of the patients who passed away had problems in the burial procedures.

For the diagnosis of COVID -19, both clinical, radiological, and PCR tests were used in most of the patients ( $n=54,87.1 \%$ ). It was determined that $71 \%(n=44)$ of the patients in the centers were admitted from the emergency services, other wards in-hospital, and other hospitals through the emergency call center (calling 112).

Thirty-eight participants (61.3\%) stated that they used all PPE in their units, and all participants used at least surgical masks or N95 masks with gloves (Table-3). Most of the participants ( $\mathrm{n}=$ $57,91.9 \%$ ) were using all PPE, even if the patients had a probable COVID-19 case, while 20 participants (32.3\%) were using all PPE in negative cases. The number of teams using all PPE while approaching patients with negative COVID PCR test was less ( $\mathrm{n}=$ $42,67.7 \%)$. In procedures involving aerosol, the number of clinics using all PPE was less ( $n=10,16.1 \%)$, all participants at least used surgical masks or $\mathrm{N} 95$ masks and gloves, 4 participants (6.5\%) stated that they did not use N95 masks.

Patients with clinical and radiological appearance of viral pneumonia were admitted to the ICU for probable COVID-19 pneumonia treatment $(n=7,11.3 \%)$, exclusion $(n=7,11.3 \%)$ and both ( $\mathrm{n}=48,77.4 \%)$.

Out of $80.6 \%$ of the participants ( $n=50$ ) who received information about the COVID-19 disease, 65.4\% ( $n=34$ ) received this information through in-house training, $93.5 \%$
( $n=58$ ) followed the ministry of health guidelines, $32.3 \%$ ( $n=20$ ) of them stated that they also read non-ministry of health resources, and $95.2 \%(n=59)$ of them stated that they prepared protocols for admission and treatment of patients.

Thirty seven participants $(59.7 \%)$ stated that they did not feel safe while caring for the patients, and the most common reason for their insecurity was the fear of contamination (70.3\%). Others were PPE insufficiency (18.9\%) and having an underlying chronic disease (10.8\%), respectively.

The anxiety levels of the doctors and nurses working in the ICU are presented in Table-4. Fifty four (87.1\%) participants stated that they were not diagnosed with panic disorder, anxiety disorder, or obsessive-compulsive disorder before the pandemic. Thirty eight participants $(61.3 \%)$ stated that they did not have any psychiatric complaints during this period.

\begin{tabular}{l|c|c|}
\hline $\begin{array}{l}\text { Table-4: Anxiety levels of doctors and nurses } \\
\text { Levels }\end{array}$ & \\
\hline Doctors (n/\%) & Nurses (n/\%) \\
\hline Low & $1 / 1.6$ & $3 / 4.8$ \\
\hline Hedium & $43 / 69.4$ & $27 / 43.5$ \\
\hline High & $18 / 29.0$ & $32 / 51.6$ \\
\hline
\end{tabular}

No statistically significant difference was found between the level of anxiety related to COVID-19 disease and professional title $(p>0.05)$. The anxiety levels associated with COVID-19 disease between the participants who were previously diagnosed with anxiety, and those who did not were similar. While it was observed that the anxiety level of ICU physicians decreased as the number of patients followed up increased ( $p$ $=0.025$ ), the increasing number of hospital beds was found to be significantly associated with increased anxiety levels $(p=0.015)$ (Table-5). No statistically significant difference was found between the content and number of PPE and the anxiety level $(p=0.052)$. According to the multivariate logistic regression model, it was found that the presence of anxiety complaints increased the state of having high anxiety related to COVID-19 disease 28.3 times ( $p=0.001$ ) (Table-6).

\begin{tabular}{|c|c|c|c|c|c|}
\hline \multirow{2}{*}{ Anxiety levels } & \multicolumn{2}{|c|}{ Medium Level } & \multicolumn{2}{|c|}{ High Level } & \multirow[b]{2}{*}{$P$ value } \\
\hline & Mean \pm SD & Median (Min.-Max.) & Mean \pm SD & Median (Min.-Max.) & \\
\hline Age (years) & $40.2 \pm 9.6$ & $41.0(27-60)$ & $38.1 \pm 7.9$ & $39.0(27-51)$ & 0.408 \\
\hline Number of hospital beds & $248.7 \pm 133.4$ & $292.5(32-450)$ & $359.8 \pm 192.2$ & $400.0(27-600)$ & 0.015 \\
\hline Number of ICU beds & $30.9 \pm 11.9$ & $30.0(6-60)$ & $25.8 \pm 12.9$ & $26.0(6-60)$ & 0.145 \\
\hline Number of Patients for doctors & $12.6 \pm 6.8$ & $12.0(4-36)$ & $8.4 \pm 5.3$ & $6.0(4-27)$ & 0.025 \\
\hline Number of Patients for nurses & $4.1 \pm 4.9$ & $3.0(2-12)$ & $2.3 \pm 0.49$ & $2.0(2-3)$ & 0.142 \\
\hline Working duration of doctors (hours) & $10.5 \pm 5.2$ & $9.0(8-30)$ & $12.7 \pm 5.9$ & $10.0(6-26)$ & 0.155 \\
\hline Working duration of nurses (hours) & $10.8 \pm 1.8$ & $12.0(8-12)$ & $10.6 \pm 2.2$ & $12.0(6-12)$ & 0.681 \\
\hline \multicolumn{6}{|c|}{ SD: Standart deviation, Min: minimum, Max: maximum, ICU: Intensive Care Unit } \\
\hline
\end{tabular}




\begin{tabular}{|c|c|c|c|c|c|}
\hline & \multirow[b]{2}{*}{ SE } & \multirow[b]{2}{*}{ Exp B (Odds) } & \multirow[b]{2}{*}{$P$ value } & \multicolumn{2}{|c|}{ \%95 Confidence Interval } \\
\hline & & & & Lower limit & $\begin{array}{l}\text { Upper } \\
\text { limit }\end{array}$ \\
\hline Number of hospital beds & 0.003 & 1.004 & 0.245 & 0.997 & 1.011 \\
\hline Number of Patients per doctors & 0.197 & 0.718 & 0.092 & 0.489 & 1.056 \\
\hline Complaint of anxiety & 1.014 & 28.330 & 0.001 & 3.884 & 206.643 \\
\hline
\end{tabular}

\section{Discussion}

We conducted a survey, consisting of 53 questions examining the difficulties faced during the COVID-19 pandemic, with 62 doctors physicians in charge of ICU of Başkent University hospitals. It was determined that more than $90 \%$ of the participants had sufficient knowledge about this disease through the trainings given by the institution they are working at and their own researches, and more than 95\% of them created a protocol for admission and management of critically ill COVID-19 patients. Although more than $80 \%$ of the participants stated that they have sufficient personal protective equipment (PPE), more than half of the participants stated that they don't feel safe while caring for the patient. The most common reason for this insecurity was found to be the fear of infecting their families and close contacts. We found that the anxiety levels of the doctors who had anxiety complaints before are higher than the others, and also increase in the number of beds in the hospital is related with the anxiety level of the doctors and that there is a decrease in the anxiety level of intensive care doctors in parallel with the increase in the number of patients treated.

As a result of the survey, $69.4 \%$ of the doctors working in the intensive care unit (ICU) stated that their anxiety level was moderate, while $29 \%$ stated that it was at a higher level. It is known that healthcare professionals working in ICU have been in the frontline of the COVID-19 pandemic from the very beginning.[8] In studies conducted out of the ICU, it has been reported that insomnia, anxiety, and depression were observed at a high rate in healthcare professionals who participated in the treatment of COVID-19 patients.[9] In a survey conducted with healthcare professionals working in ICU, it was reported that anxiety and depression were observed in more than $50 \%$ of the healthcare professionals.[9] In accordance with these studies, it was found that particularly the moderate anxiety rate of the doctors participating in our study was more than $50 \%$. Also, the doctors stated that especially female nurses working in the covid ICU have higher anxiety levels in accordance with the literature, and they observed high anxiety in $50 \%$ of the nurses.[10,11] We attribute this to the fact that nurses are in close contact with COVID-19 PCR positive patients for longer periods of time for treatment. Of course, this data is entirely based on the observation of the doctors participating in the survey. A survey wasn't conducted with nurses working in the COVID-19 ICU. As in the article by Elina et al., we determined that the most important reason for the increase in anxiety of the participants is the fear of infecting their families and close contacts despite having the sufficient PPE, and this fear was detected in more than half of the participants.[12] When compared with the other participants, no difference was found in the anxiety levels of the participants who were diagnosed with anxiety and received treatment before. It was found that the participants's anxiety levels, who did not have an anxiety diagnosis and treatment but had anxiety complaints before, were higher than the others. We attribute this to the fact that the treatment participants with anxiety diagnosis receiving for their existing complaints might have suppressed their covidrelated anxiety, and that the complaints of the participants who did not receive any treatment even though they had anxiety complaints before may have been triggered further. Different from the findings of Azoulay et al., we found that there is no significant relationship between age, experience, academic title, and anxiety levels.[13] Contrary to what was expected, we did not conclude that anxiety decreased with increasing age and experience. Again contrary to findings of Azoulay et al., we found that there is a statistically significant decrease in the anxiety level of doctors in parallel with the increase in the number of patients treated.[13] We attribute this to the fact that the doctors who take care of more patients get to know this disease better and control their fears as they get to know it. In accordance with other publications, we think that the unknowns about the course and results of this new disease cause more anxiety in healthcare professionals.[12,14] In our study, we found that the increase in the number of beds 
in hospital have a statistically significant relationship with the anxiety level of doctors working in the ICU. We think that the reason for this may be the possibility that the number of beds in the ICU can not meet the potential number of patients who need to be admitted to ICU and may cause blockage.

The low number of doctors participating in our study and the fact that the level of anxiety was evaluated by how the participants feel themselves rather than a valid test, are the limitations of our study. This study was planned before the vaccination process against COVID-19 so if it had been done after the vaccination of healthcare workers, the results could have been different.

\section{Conclusion}

In conclusion, we have found out that although more than half of the participants have sufficient PPE, they don't feel safe due to the fear of infecting their families and close contacts. We also found that the anxiety levels of the doctors who had anxiety complaints before were higher than the others, and also increase in the number of beds in the hospital is related with the anxiety level of the doctors and that there is a decrease in the anxiety level of intensive care doctors in parallel with the increase in the number of patients treated. We think that in the future, more reliable results will be obtained with the planning of more comprehensive studies including not only doctors but also otherhealthcare professionals working in the COVID-19 intensive care unit and using international objective scales measuring the anxiety levels.

\section{Declaration of conflict of interest}

The authors received no financial support for the research and/or authorship of this article. There is no conflict of interest.

*Presented as an Oral Presentation at Anesthesiology and Reanimation Specialists' Society Congress-Balkan Satates Anesthesia Days VII International Congress 30.04.202102.05.2021.

\section{References}

1. WHO. Novel coronavirus - China. Jan 12, 2020. http://www. who. int/csr/don/12-january-2020-novel-coronavirus-china/en/ (accessed Jan 19, 2020).

2. Sağlık Bakanlığı Halk Sağlı̆ı Genel Müdürlüğü COVID-19 (SARSCov-2 Enfeksiyonu) Rehberi Bilim Kurulu Çalışması https:// covid19bilgi.saglik.gov.tr/depo/rehberler/COVID-19_Rehberi.pdf
3. Grasselli G, Zangrillo A, Zanella A et al. Baseline Characteristics and Outcomes of 1591 Patients Infected With SARS-CoV-2 Admitted to ICUs of the Lombardy Region, Italy. JAMA 2020; 323: 1574-81. Erratum in: JAMA 2021; 325: 2120

4. Centers for Disease Control and Prevention https://www.cdc. gov/flu/pandemic-resources/1918-commemoration/pandemictimeline-1918.htm

5. Freitas ARR, Napimoga M, Donalisio MR. Assessing the severity of COVID-19. Epidemiol Serv Saude 2020; 29: 2020119

6. Reed $C$, Biggerstaff $M$, Finelli $L$ et al. Novel framework for assessing epidemiologic effects of influenza epidemics and pandemics. Emerg Infect Dis 2013; 19: 85-91.

7. https://www.psikiyatri.org.tr/uploadFiles/213202011418saglikcalisanibrosur.pdf

8. Alhazzani W, Møller MH, Arabi YM et al. Surviving Sepsis Campaign: guidelines on the management of critically ill adults with Coronavirus Disease 2019 (COVID-19). Intensive Care Med 2020; 46: 854-87.

9. Pappa S, Ntella V, Giannakas T, Giannakoulis VG, Papoutsi E, Katsaounou P. Prevalence of depression, anxiety, and insomnia among healthcare workers during the COVID-19 pandemic: A systematic review and meta-analysis. Brain Behav Immun. 2020; 88: 901-7. Erratum in: Brain Behav Immun 2021; 92: 247.

10. Lai J, Ma S, Wang $Y$ et al. Factors Associated With Mental Health Outcomes Among Health Care Workers Exposed to Coronavirus Disease 2019. JAMA Netw Open 2020; 3: 203976.

11. Preti E, Di Mattei V, Perego G et al. The Psychological Impact of Epidemic and Pandemic Outbreaks on Healthcare Workers: Rapid Review of the Evidence. Curr Psychiatry Rep 2020; 22: 43.

12. Mattila E, Peltokoski J, Neva MH, Kaunonen M, Helminen M, Parkkila AK. COVID-19: anxiety among hospital staff and associated factors. Ann Med 2021; 53: 237-46.

13. Azoulay E, De Waele J, Ferrer R et al. Symptoms of burnout in intensive care unit specialists facing the COVID-19 outbreak. Ann Intensive Care 2020; 10: 110.

14. $\mathrm{Xu} \mathrm{J,} \mathrm{Xu} \mathrm{QH}$, Wang $\mathrm{CM}$, Wang J. Psychological status of surgical staff during the COVID-19 outbreak. Psychiatry Res 2020; 288: 112955. 